\title{
The Development of Natural Disaster Digital Literacy (DILIBA) Android Based of Students' Understanding at Primary Teacher Education Study Program, Peradaban University.
}

\author{
${ }^{1}$ Yuni Suprapto, ${ }^{2}$ Eka Farida Fasha, ${ }^{3}$ Dewi Liesnoor S, ${ }^{4}$ Erni Suharini \\ 1 asuprapto666@gmail.com, ${ }^{2}$ ekafaridafasha@yahoo.co.id, ${ }^{3}$ liesnoor@yahoo.co.id, \\ 4ernisuharini@gmail.com \\ ${ }^{1,2}$ Fakultas Keguruan dan Ilmu Pendidikan Universitas Peradaban Brebes, Indonesia, \\ ${ }^{3,4}$ Social Science Faculty Semarang State University Semarang, Indonesia
}

\begin{abstract}
The used of internet, by increasingly gadget usage of Indonesian as much as 132,7, should be able to use positive thing such as developing natural disaster digital literacy. Indonesia territory is located in natural disaster prone area, such as hydrometeorology. It is included annual natural disaster which always hit Indonesia; flood and landslide disasters have high intensity. To minimize it Government collaborate with college has various effort to overcome it; however, natural disaster costs caused by hidrometeorologi still occurred especially on rainy season. Based on that case, it is needed to natural disaster education to the community by using the newest technology which can be used by anyone, anywhere and anytime such natural disaster digital literacy, this breakthrough can be done by habituating academic community as the user of the technology, they are the college students to utilize their gadget as media of natural disaster digital literacy. The development of digital media, facilitate natural disaster education enforcement for the college. Based on the case, researcher deliver this paper entitled The Development Concept of Natural disaster Digital Literacy (DILIBA) Android Based of Students' Understanding at Primary Teacher Education Study Program, Peradaban University. The aim of this research: 1) Draw up an understanding material of hidrometeorologi natural disaster for students of Primary Teacher Education Study Program, Peradaban University; 2) Create development concept of digital literacy Media Android based (DILIBA); 3) Make a digital comic application concept of natural disaster that can be used in all phone android based.
\end{abstract}

Keyword: Digital Literacy, Natural disaster, college students, Primary Teacher Education (PGSD) Study Program

\section{Introdution}

Information technology (IT) development bring us to the disruption era, the era where old pattern and order changes rapidly and fundamentally. This era create unlimited IT consumers and consist of many circles. Internet users in Indonesia that has 132.7 millionusers in 2017, already grow 143.26 millions, from 256.2 million of Indonesia's population. This marks that internet user in Indonesia reach $54.68 \%$ from Indonesia's population. The differences between male and female internet users in that percentage were fair enough, which $51.43 \%$ male and 48.57 female. For the dispersion of internet users, it is $72.41 \%$ in urban area, $49.49 \%$ in rural-urban and $48.25 \%$ in rural area. Anyhow, internet users spread mostly in Java $(58.08 \%)$, the others followed in Sumatera (19.05\%), Sulawesi $(6.73 \%)$, and Kalimantan 
(5.63\%) geographically. The others two regions, Bali and Nusa Tenggara were below 6\%. This showed that there is disparity in internet usage[1][2].

The disparity also showed in age context, from all the internet users, the dominant one is $35-54$ year age group $(29.55 \%)$, followed $19-34$ years which has $49.52 \%$. In third place, there are $13-18$ years $(16.68 \%$, followed by $>54$ years which has $4.24 \%$. meanwhile internet users based on education level dominate by Master and $\mathrm{Ph}$. D (88.24\%). For the media or device used to access the internet dominated by Smartphone $(50.08 \%)$ and personal computer (PC)/Notebook (25.72\%). Paid apps used by $11.41 \%$ users, meanwhile subscribe apps used by $6.29 \%$ users. From professional perspective, internet users dominate by work group or entrepreneur $(62 \%)$ or 82.2 million users. Surprisingly, in the second place was housewife (16.6\%) or 22 million users. College student were in third place with 10.3 million users $(7.8 \%)$ and student group with 8.3 million users $(6.3 \%)$.

The content accessed topped by social media $97.4 \%$ or 129.2 million users' access it. Next content mostly accessed by internet users was entertainment with 128.4 million users (96.8\%). In third place, there are news content with 124.4 million users (93.8\%), followed by commercial content (93.1\% or 123.5 million users) and public service (121.5 million users or 91.6\%). Facebook still topped media social accessed by Indonesian internet users by $54 \%$ (71.6 million users), followed by Instagram by 15\% (19.9 million users) and YouTube $11 \%$ (14.5 million users). Shockingly, Twitter users just have 7.2 million users (5.5\%). It means, Twitter which in other countries got its supremacy, didn't happen in Indonesia. Actually, there are many other data about internet users behavior in Indonesia which can be extracted from 2016 APJII survey report.

\subsection{The Structure \\ a. Background}

APJII's survey data in 2016 and 2017 showed that numbers of internet users in Indonesia access by gadget, also the increasing frequency of information and social media content accessed. Unfortunately, if we tracked these gadget usage, rooted from the low digital literacy of Indonesian. Started from that reality, various parties tried to increase digital literacy in the society. The effort which already began some years ago did by various approaches to finish some issues regarding digital problem. Increasing the level of public literacy or make the society aware in digital context is not a task which can be translated in just one or two approaches. But, it must be done through various sides. With the high gadget usage by the Indonesian, actually can be used to the more positive side.

Indonesia is a country which has natural disaster potency which comes from the nature or as an impact from human exploitation in the nature. Disaster define as an event or progress of event which threaten and disturb society's live and live hood caused by natural factor and/or non-nature factor as well as human factor that inflict dead victim, environment damage, loss of property, and psychological impact[3]. Yearly disaster which always happened in Indonesia is hydrometeorology disaster, such as flood and landslide. Many attempts to minimize and prevent flood and landslide already did by the regional government, collaborate with some college, however, the loss caused by the disaster still happen especially in the monsoon/rainy season. To reduce the risk of disaster and development planning that save and sustainable, there is a need to do disaster education in the society with the newest technology. 
The government must facilitate and give disaster education for the society. It is because there is the need to facilitate the implementation of disaster education for the society by increasing natural disaster digital literacy. This year, there is flood and landslide happened in Brebes Regency, some districts got impacted like wrecked house, 8 dead victims by this disaster. Meanwhile landslide also gives psychological damage or after disaster trauma. From this problem, it needed preventive attempt which can minimize the victims impacted by the landslide disaster. One way that can be done was natural disaster digital literacy concept based android which can be used by student of PGSD department. Based on this background, the researcher made a paper titled Pengembangan Digital Literacy Bencana Alam (DILIBA) berbasis Android Untuk Pemahaman Bencana pada Mahasiswa Prodi PGSD Universitas Peradaban.

b. Rationale

The importance of this study is to utilize technology and gadget in this era for educational interest, especially natural disaster education. New option in the form of android based gadget is used as media to increase natural disaster digital literacy.

c. Problem statement

The declaration of literacy movement by the government must be done not only in the school, but the awareness to build literacy movement must be started from the smallest scope which is family. From that fact, the researcher attempt to develop natural disaster digital literacy movement with android based gadget or Smartphone.

\section{d. Objective}

From that idea, the researcher did some steps forming this research, started from developing natural disaster digital literacy conceptual study, collecting the field disaster data in Brebes Regency, creating disaster comic and video on android based phone.

e. Scope

This research limited in flood and landslide disaster happened in Brebes Regency, with the research subject in PGSD department students.

\section{Related Works/ Literature Review \\ 2.1 Literature Review \\ 2.1.1 Media Android Based Natural Disaster Digital Literacy Media}

Literacy literally translated as reading and writing abilities, on the process, reading and writingabilities only didn't enough to make human fully functioned in the society. In the essence, read and write abilities is a mean for someone to involve in many aspect of life, like doing some activities related to the knowledge, economic transaction, involve in political life, etc. According to the context, literacy developed become various kinds of literacy, like political literacy, financial literacy, law literacy, including media literacy, information literacy, and digital literacy.

Media literacy concept appeared as media domination in human life which transferred data and information used by human to his daily life. Potter noted, at first the expert define media literacy as 'the ability to access and process information from any form of transmission'. This definition then detailed as “... the ability to access, analyze, evaluate and create messages across a variety of contexts[4]. This definition that become stepping stone of the media literacy activist or education planner to integrating it in the curriculum aim to create human which functioned properly in information era. This approach interpreted as life skill approach. 
However, media growth and its phenomenon didn't enough to finish media literacy problem. It is needed new point of view not only frame working media literacy as a matter to developing life skill. Life skill approach indeed settling technical problems. However, in fact this approach also demanding media consumption in high intensity, so it difficult to control and tend to excessive. According to Potter, it is time to develop media literacy as a set of perspective that we actively use to expose ourselves to the media and interpret the meaning of the messages we encounter. It is multidimensional, and a continuum[5]. Media literacy character mentioned by Potter as multidimensional and continuum became important when the world entering new decade, which is new media. Answered Livingstone challenge which threw rhetoric-philosophic question "What's new for society about the new media?", Flew stated that new media not only about the internet, World Wide Web, or leap of information and communication technology. It is important to understand new media as the growth of media related with social and technological process in three aspects: (1) digitations and convergence; (2) interactivity; and (3) network and networking [6]. The complexity of the new media needs a new literacy ability which not only frame working media literacy as a mean to access and use media. From this point digital literacy concept emerge as a demand as well as guide line to positioning ourselves in the era of new media. Digital literacy concept disclosed by Paul Gilster in 1997, in the book titled Digital Literacy. Glister simply defines it as 'literacy in the digital age, or ability to understand and use information by various digital sources on the process digital illiteraciesdefines as 'practices of communicating, relating, thinking and 'being' associated with digital media [7].

This definition sourced from root conception of digital media development as a social phenomenon that brings many economic, social, and politic consequences. 'Practices' term chosencause this concept covers all the means to utilize literacy actively, including interpretation activity underlying it. ."Literacy practices are made up of specific activities and at the same time are parts of broader social processes... The concept provides the route map for thinking about topics as diverse as the role of agency, and the significance of the body, objects and texts. It clarifies the relations of actions and discourse. Human life are made up of social practices. That is the reason why we emphasize people's lived experiences and everyday relations to technologies ..."[8]. In virtual world where internet becomes new media that so important in daily life, it is needed an understanding and user agency cause technology just a tool which not determined how we must act[9]. Therefore, it is needed a chain of understanding and acts by applying various new media literacy known as digital literacy. The importance of digital literacy was not only caused by the high exposure of media, but also other factors that influenced it.

First, the importance's of information in democracy process. Second, the importance's of cultural and citizenship participation. Third, the growth of popular culture which made child and teenagers accessed digital media. Potter added that the importance of media literacy in this new form also driven by the height of media growth that unequal with human abilities to compensate for it. as an illustration, media developments detailed by Potter: Our culture is saturated with media messages - far more than you may realize. Hollywood releases more than 700 hours feature films each years, which adds to its base of more than 100.000 hours of films they have already released in the previous years. In addition, users of a video platform such as YouTube upload more than 100.000 new hours of video every day. Commercial television stations generate about 48 million hours of video messages every year worldwide, and radio station send out 65.5 million hours of original programming each year. We now have more than 140 million books titles in existence, and another 1.500 new book titles are published through the world each day[5]. 
Potter illustrated media growth in 2014, based on observation in 2013. New media challenges not only rooted in technological side only, or market/industrial form which accompanied it. In digital media, there are public positional changes, from passive audience to flexible audience that can reproduce the text independently due to facilities owned by the internet. In one side, this privilege is affordances. In the other side, gives pressure cause to utilize these affordances needed abilities which not only limited in mastering access and technology. Affordance always comes along with the constraints. Facing digital texts need different modalities to encounter these affordances and constraints. Also, positioning it's in mediation context in the middle of this affordances and constraints. Multimodal texts in many print-based media (and even websites) are relatively static and are created by a single author. In Web 2.0 spaces, by contrast, multimodal content can be co-created and constantly edited by multiple users. The convergence of writing spaces in new social media presents new opportunities for easy creation, posting, and sharing of multimodal texts[8]. The example above showed one impact of technological development in digital media, which is increasing multimodal content usually found in digital media combine some modalities at one, this is what called multimodality. As a result, a range of new illiteracies are needed to cope with the proliferation of images, graphics, video, animation and sound in digital texts[7]. Because of it, the use of literacy terms actually has a plural meaning not a singular one, because by increasing media convergence usage has a plural meaning which covers various literacy from series of communication and contemporary media form [10].

The process through which people appropriate these tools to accomplish particular social practices[7]. With interpreting digital literacy as a concept head to mediation between technology and user to practicing digital technology productively, then digital literacy movement can be designed and held in many regions. Digital literacy movement basically has same goal although has various activities. A digitally literate person: (1) Possesses the variety of skills - technical and cognitive - required to find, understand, evaluate, create, and communicate digital information in a wide variety of formats; (2) Is able to use diverse technologies appropriately and effectively to retrieve information, interpret results, and judge the quality of that in-formation; (3) Understands the relationship between technology, life-long learning, personal privacy, and stewardship of information; (4) Uses these skills and the appropriate technology to communicate and collaborate with peers, colleagues, family, and on occasion, the general public; and (5) Uses these skills to actively participate in civic society and contribute to a vibrant, informed, and engaged community.

Although digitalization project already started since 1980, UNESCO just reach digital literacy problem in May 2017 as follow-up of Lisbon conference. Officially, digital literacy aspects become parts of 16 indicators formulated by Education Council as a form of 'measuring information society'. These aspects are ICT skills, civic skills, learning to learn skills, and participation of adults in lifelong learning, with priority related in developing digital competence areas, including infrastructures development [11]. As a note, literacy issue just entering UNESCO's agenda in 2004, so don't be surprised if digital literacy issue comes three years later. Developed countries like United States, Canada, and Australia response UNESCO Policy Brief regarding digital literacy a year later, although various previous studies and activities in education realm started since 2006, among them through great project of Digital Information Forecast Research 2006-2011 and Project of Information Literacy which started since 2008[12].

Asia's countries like China and Japan also tried to rivaling developed countries pace in acquiring digital literacy concept to developing human resources. India and Singapore also not left behind. In Africa continent, South Africa became a country that progressive enough in 
including digital literacy as a part of formal educational curriculum. It started from college level 2012, then digital literacy adopted as a part of basic curriculum. In student's level, study related digital literacy generally started in 2010, and then continued to more specific topics, like utilization of blogging, visual arts by digital media, and digital storytelling and music making. Many digital literacy studiesalready exist showed that digital literacy was mandatory to be included in Indonesia's educational curriculum. Moreover natural disaster digital literacy media, natural disaster digital literacy is digital media used as a tool to increase natural disaster understanding for the users. These media can be in form of digital comic, disaster video, or natural disaster game.

Sharpe \& Izadkhahtells their research results, by their journal titled Use Of Comic Strips In Teaching Earthquakes to kindergarten children. This research stated that This Pilot Study Showed That Comic Strips Were Considered By Children To Be Their Favourite Way To Learn About Earthquakes. This research showed that comic strips considered by the child as a fun way to studying earthquakes[13].

The journal titled "The Effect Of Comic Strips On EFL Reading Comprehension", tells that "Finally, As The Research Interest Of This Study, Comic Strip Use Had A Significant Effect On Students' recall of both the high level and low level texts for both high proficient and low proficient learners of English"[14]. The conclusion of this research, strips comic has a significant effect in terms of students' memories between difficult and easy texts, for high and low skills towards the learners of English. The similarity with the research that we will conduct is in term of comic use in learning process. Comic not only used as entertainment only, but also can be used in many science. According to comic can be used as learning tools.

The pictures in comic usually are in form of cartoon. Comic has simplicity in its presentation, and has sequences of story that gives big messages but presented in a brief but easy to understand. Besides that, comic also equipped with verbal and non-verbal languages which accelerating the reader to understand the content, because the readers helped to stay focused in the storyline. So, comic is a visual media which contained pictures story that tells an event, can be functioned as an entertainment media and delivery of learning messages which easy to understand by the children. Digital natural disaster comic is a comic that has story which tells a natural disaster event involving some characters interacted and communicated each other's relating natural disaster event and its countermeasures. A disaster comic is an alternative to give natural disaster understanding to the society. This android based digital natural disaster comic is an interesting media in delivering messages because accompanied with pictures and adjusted with the environment around the community.

\subsubsection{Previous Research}

The natural disaster research topics and disaster preparedness already conducted before, nut with different titled and results. These are some research that researcher used as reference:

Pengembangan Model Sekolah Siaga Bencana Melalui Integrasi Pengurangan Risiko Bencana dalam Kurikulum, the results are: 1). Professional competence side of the teachers felt lack of knowlwdge regarding disaster material and handling disaster risk; 2) in pedagogically competence side, the teacher still not used cooperative learning method (active learning); 3) socially competence side need to increase the closer communication in school environments; 4) personally competence side need to increase awareness and responsibility in disaster preparedness[15].

Titled Efektifitas Dampak Pendidikan Kebencanaan di Sekolah Terhadap Kesiapsiagaan Menghadapi Bencana Tsunami di Aceh, Indonesia, funded by disaster risk reduction Aplplication (DRR-A) in 2011, method used in this research was survey by handing 
out questioner to the students which applying Sekolah SIaga Bencana (SSB) in their curriculum and school which not yet applying SSB. The results of this research were; a) the school that adopted disasters issue in their curriculum was effective in increasing disasters knowledge; b) the school that adopted it capable to increasing risk perception, individual and school preparedness; c) last founding which most important was the result of disaster issue application in school curriculum can increasing students preparedness, although in the general definition that disaster was God's punishment as main reason[16].

Astuti did a research titled Pelaksanaan Program Sekolah Siaga Bencana Di SMA Negeri 1 Karanganom Klaten, which resulted 1) highest disaster potency in school environment was earthquakes, besides that there are threat of typhoons; 2) The overall average in the implementation of the Karanganom 1 High School Public Disaster Preparedness School Program is $79.8 \%$. The most fulfilled component is the Resource Mobilization component which reaches $91.6 \%[17]$.

Bartolucci's did a researchtitled Influence Rather than Control: A New Approach for Disaster Education in The Immediate AfterMath of Disaster. This researched tells about alternative approach based on decisions diagram flow which can be used to build education program according to adaptation necessity from the survivors of disaster to consider them as resources that can be enhanced by empowerment in disaster preparedness activities. This research applies three different approaches, two steps about disaster education and one step to provide disaster video. Research shows that the average value of respondents trained in using a new approach to disaster education has succeeded in influencing their reaction to a disaster situation. This study provides an evidence-based approach that can be used to improve the effectiveness of training, education and disaster management programs, these programs are shown in improving the adaptability of survivors in disasters[18].

Jiuh Wang's researchtitled Study on The Context of Based Disaster Management. This research arranges a scoring framework for disaster management in schools, which includes the concept of scenario management, disaster awareness, and disaster psychology, disaster management roadmap in schools, and the integrity and validity of disaster simulations, the evaluations was based on thirty-five school samples in Taiwan. The result was that these thirty-five schools are capably of adequate investment, school involvement and readiness. However, there are deficiencies, that schools do not involve external factors that must be utilized further to increase and improve their disaster management performance[19].

Tatebe's researchtitled Perspectives on education, children and young people disaster risk reduction tells about the perspective of disaster education, includes; 1) prevention and planning; 2) disaster management; 3) and focus on education, the point is that disaster education contributes to the dissemination of relevant knowledge and information regarding risk, vulnerabilities, and capacities, disaster education is also associated with community empowerment in the long term[20].

\section{Material and Methodology \\ 3.1 Data}

The data taken was data on the number of natural disasters in Central Java province in 2018 and data on the occurrence of natural disasters in Brebes in the same year, after obtaining data on natural disasters, researchers made a tool for natural disasters learning, then digital natural disasters videos and comics were made that used as android-based digital learning media. 


\subsection{Method and Development Procedure}

The development that carried out in this research were; 1) media Digital Literacy Bencana Alam (DILIBA); 2) DILIBA application on android phones. This research refers to Fenrich's (1997) instructional development cycle which includes the analysis phase, the planning, design, development, implementation, evaluation and revision phases.

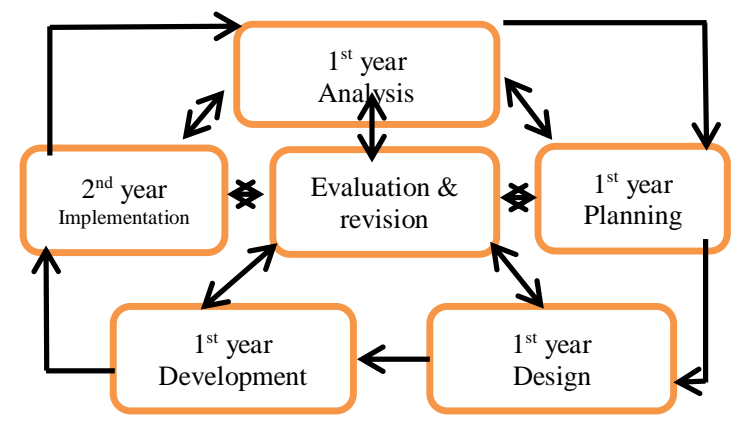

Figure 1. Model of the Instructional Development Cycle[21].

The development model as in Figure 1 will be used in the development of DILIBA learning media for the community, which was conducted in this research. The instructional development cycle includes analysis, planning, design, development, implementation, evaluation and revision. The evaluation and revision phases are ongoing activities carried out in each phase throughout the development cycle. Each phase is evaluated for the results of these activities and revised according to the evaluation results, and continued in the next phase [21].

Theoretical phase is carried out an analysis of hydro meteorological natural disasters that occur in Central Java Province and Brebes Regency, then compiles a literature review to obtain an overview of; a) types of disasters around the Bumiayu district; b) annual disasters that often occur in Bumiayu district; c) the disaster analysis then used as material and content in the DILIBA media; d) during this phase evaluation and revision are then carried out. Planning phase was done by creating learning media. DILIBA media begins with designing the contents of the material or content, in DILIBA displays various kinds of natural and nonnatural disasters, then about disasters that often occur around Brebes Regency, then after finished, then designing the contents of DILIBA which is in accordance with the context of hydro meteorological disasters in Brebes Regency namely floods and landslides. During the planning phase, evaluation and revision were carried out, the design phase was carried out by the arrangement of DILIBA learning media starting from layout design, then animation, and the storyline of DILIBA, during this phase evaluation and revision were carried out. After the design was made, then an application was made on an Android phone. In this phase evaluation and revision were carried out.

During the development phase, BPBD reviewed and validated the DILIBA draft, in this phase a workshop on validation and review was conducted by digital media experts. Aspects that are considered in reviewing DILIBA are; 1) layout; 2) storyline; 3) color games; 4) content ; 5) and ease of use of applications on Android phones. Advice and input provided by digital media experts, BPBD, for the use on android phones. Then the DILIBA media test was conducted. In the implementation phase, the application of DILIBA to all PGSD 
department students in Social Science courses, then small-scale trial was conducted on improving disaster understanding by using DILIBA to determine the level of Literacy in natural disaster students of PGSD department.

\section{Result and Discussion}

Natural disasters in Brebes Regency that often occur, was Hydro meteorological disasters are floods and landslides, the existing potential for disasters in Brebes regency needs a good disaster awareness habituation in all components of society, especially for college students. The development of natural disaster digital literacy media that was developed focused on two media namely disaster digital comics and disaster video, while later on further development will lead to disaster gamification.The steps in creating this media literacy are preliminary data in form of data on natural disasters which occurred in Brebes in 2018 and areas affected by natural disasters collected for a natural disaster learning tool, after the device was completed then create a digital comic story natural disasters in which there are various kinds of natural disasters material, Indonesia's astronomical and geographical position that are susceptible for natural disasters, and natural disaster mitigation.The aspect emphasized in the development of digital literacy media was on aspects of knowledge, aspects of behavior and skills aspects of dealing with natural disasters. The development of digital literacy is in accordance with the criteria of knowledge conveyed by Dale, that students will more easily understand a knowledge if they experience it themselves and the audio visual level has a higher percentage of understanding than the level of listening and reading, meaning that digital literacy of natural disasters is very appropriate if it is used to increase understanding of disasters for students.

\section{Conclusion}

Digital natural disaster literacy, proven to be able to improve natural disasters understanding of students which include aspects of natural disaster knowledge, various natural disasters, factors of natural disasters, and mitigation of natural disasters in this context is mitigation of natural disasters landslides and floods that occur in Brebes Regency.

\section{Acknowledgment}

This research supported by research grant from the Kementerian Riset, Teknologi, dan Pendidikan Tinggi Republic of Indonesia. This research also supported by Universitas Peradaban, and Universitas Negeri Semarang as partner research team.

\section{References}

[1] Asosiasi Penyelenggara Jasa Iinternet Indonesia, "Infografis Penentrasi dan Perilaku Pengguna Internet Indonesia Survey 2017," APJII, 2017.

[2] Asosiasi Penyelengara Jasa Internet Indonesia, "Infografis Penetrasi dan Perilaku Pengguna Internet Indonesia Survey 2016," APJII, 2016.

[3] Presiden Republik Indonesia, "Undang-Undang Republik Indonesia Nomor 24 Tahun 2007 tentang Penanggulangan Bencana," 26 April 2007. [Online]. Available: https://www.bnpb.go.id/ppid/file/UU_24_2007.pdf. [Accessed 13 May 2018].

[4] S. Livingstone, "The Changing Nature and Uses of Media Literacy," Media@LSE 
electronic working papers, vol. 4, pp. 1-31, 2003.

[5] W. J. Potter, "Guideline for Media Literacy Interventiions in the digital Age," Izvorni Znanstveni Rad, vol. 20, no. 2, pp. 5-29, 2014.

[6] T. Flew, A. Bruns, J. Burgess, O. Ben-Harush, E. Potter and J. Newton, "Support Frameworks for the Use of Social Media by Emergency Management Organisations," QUT Digital Media Research Centre, Brisbane, 2015.

[7] R. H. Jones and C. A. Hafner, Understanding Digital Literacies: A Practical Introduction, New York: Routledge, 2012.

[8] D. Barton and C. Lee, Language Online: Investigating Digital Text and Practice, New York: Routledge, 2013.

[9] T. Koltay, "The Media and the Literacies: Media Literacy, Information Literacy, Digital Literacy," Sage Journal, vol. 33, no. 2, pp. 211-221, 2011.

[10] D. Buckingham, Media Education: Literacy, Learning and Contemporary Culture, Cambridge: Polity Press, 2003.

[11] UNESCO Institute for Information Technologies Education, "IITE Policy Briefs," IITE, 2012.

[12] A. J. Head and M. B. Eisenberg, "What Today's College Student Say about Conducting Research in the Digital Age," The Information School, University Of Washington , Washington, 2009.

[13] J. S. Y. O. Izadkah, "Use Of Comic Strips In Teaching Eartquake to Kindergarden Children," Disaster Prevention and Management, vol. 23, no. 2, pp. 138-156, 2013.

[14] A. Merc, "The Effect Comics Strip on EFL Reading Comprehension," International Journal on New Trend in Education and Their Implication, vol. 4, no. 1, pp. 54-64, 2013.

[15] A. K. Setyawan, "Pengembangan Model Sekolah Siaga Bencana Melalui Pengurangan Risiko Bencana dalam Kurikulum," UNY, Yogyakarta, 2010.

[16] W. Adiyoso and H. Kanagae, "Efektifitas Dampak Penetapan Pendidikan Kebencanaan di Sekolah terhadap Kesiapsiagaan Siswa Menghadapi Bencana Tsunami di Aceh," INDD Spread 31-44, 2013.

[17] A. Astuti, "Pelaksanaan Program Siaga Bencana di SMA N 1 Karanganom Klaten," UNNES, Semarang, 2015.

[18] A. Bartoluchi and M. Magni, "Influence Rather Than Control: A new Aprroach for Disaster Education In The Mediate After Math of Disaster," International Journal of Disaster Risk Reduction, vol. 19, pp. 112-117, 2016.

[19] W. J. Jeh, "Study Content of School Based Disaster Management," International Journal Of Disaster Risk Education, vol. 19, pp. 224-234, 2016.

[20] J. Tatebe and C. Mutch, "Perspektif On Education, Children and Young People Disaster Risk Reduction," International Journal Of Disaster Risk Education Elsevier, vol. 19, pp. 108-114, 2016.

[21] F. P, Practical Guidline for Creathing Instructional Multimedia Aplication, College Publisher, 1997. 
